\title{
Total Quality Management and Its Impact on the Policies and Practices of Human Resource Management in Wahda Bank in Tripoli
}

\author{
Mustafa Mohamed M Atwati ${ }^{1}$, Umar Nimran, ${ }^{2}$, M. Al Musadieq ${ }^{3}$, \\ ${ }^{I}$ (Business Administration / University of BRAWIJAYA, Indonesia, Malang)
}

\begin{abstract}
The purpose of this report is to define the quality, productivity and improvement problems that face Wahda Bank considered it as one of the banks operating in Tripoli - Libya, which seeks to provide the best administrative services. The Total Quality Management takes a form of approach or a comprehensive management system within the wahda bank based on the radical changes for all the processes that take place in the bank in which include changes thought, behavior, values, beliefs ,organizational, management concepts, management leadership style, systems and work procedures and performance in order to improve and development of all the components in the organization to reach the highest quality in their output of services, in order to achieve the highest degree of satisfaction to its customers by satisfying their needs and desires according to their expectations. This report aim to study and examining the gains of apply total quality management with particular reference to wahda bank in Tripoli and also to see how TQM can prevent future threats in the bank.
\end{abstract}

Keywords - Total Quality Management, human resource, Definition, impact.

\section{INTRODUCTION}

The spread of the phenomenon of globalization accompanied by the use of modern technology and increased customer awareness of the importance of the quality of products and services offered make organizations to apply international standards unified quality, which is measured on the basis of the performance and efficiency of organizations, as globalization has led to a revolution in the field of service and spread the concept of quality in services and especially the banking ones.

Banks in Libya facing development and expansion experience by the private sector represented by the conventional and Islamic banks, this led to increase the work in the government banks which were monopolize the market in Libya without any competition, and this is what makes the search for ways in which to keep the government banks in the banking sector provided and maintain an active role through all of the requirements of the development and performance techniques to take advantage of the available human resources to provide more services on the resilience and the ability to face competition in the market.

\subsection{Problem statement}

a. Do the policies and practices of human resource management in Wahda Bank replace current application with the concepts of Total Quality Management?

b. What are the components should be available to apply the entrance of Total Quality Management in human resource management in Wahda Bank?

c. What are the necessary results expected from applying Total Quality Management entrance to improve the policies and practices of Total Quality Management in Wahda Bank in place of the current application?

\subsection{Report Objectives.}

a. Characterize and analyze the policies and practices of Total Quality Management in Wahda Bank and determine their suitability for the application of Total Quality Management entrance.

b. Determine the intellectual and philosophical framework for the entrance of Total Quality Management as a recent trend in the field of human resource management and Administrative method aims to continuous improvement of the quality of the performance within Wahda Bank.

c. Determine the elements of the successful implementation of programs and methods to improve the Total Quality Management policies and practices of human resource management and the application of this system on the quality of Wahda Bank services. 


\section{The ConcePt OF TOTAL QUality Management}

The concept of Total Quality Management is one of the modern management concepts that aim to improve and develop the performance on an ongoing basis through the response to the requirements of the customers. There are many definitions of the concept Total Quality Management: the researchers differ in their definition.

a. Cooperative is a form of business performance depends on the capacity of each of the common management and employees, with the aim of continuous improvement in quality and productivity through team work.

b. Continuous improvement of quality, productivity and efficiency

c. The continues development of administrative processes and reviewing and analyzing a research means to raise the level of the performance and reduce the time to complete the achievements by cutting out all the tasks and functions that are useless and unnecessary for the customers or for the process to reduce the cost and raise the quality level quality at all stages of development on the requirements and needs of the customers.

\subsection{The Concept of Total Quality Management Service}

The Service that provided by the organization or bank through which a certain value for each of the owners of the capital, the customers and the employees it must take into consideration of:
a. The Importance of the support of all the leadership and team work and work style.
b. Both the organization and the customers' Needs.
c. The employees needs in the organization.

\subsection{The Basic Requirements for the Success of the Application of Total Quality Management \\ 1. The organization cultural study and understanding.}

Total Quality management culture is different from the traditional administrative culture, therefore the organization need to find the appropriate culture for the application of the concept of Total Quality Management and change management techniques.

2. The program promotion and marketing.

To apply the concepts and principles of total quality management for all employees in the organization is an essential process before Decision-Making on the application. The program is promoted by organizing lectures, conferences and training the definition of the concept of Total Quality Management and its benefits to the enterprise.

3. The Education and the Training.

To apply the concept of total quality management properly, must train and teach participants the methods and tools of this concept. The purpose of the training is to raise the awareness of the participants to identify the methods of development in the organization.

4. The use of consultants.

The purpose of the use of external expertise from consultants and specialized institutions when implementing the program is to strengthen the institution and experience to assist them in solving the problems that arise, especially in the early stages.

5. The encouragement and motivation.

The individual appreciation for doing a great job will lead to encourage the rest of the employees, and instill the confidence and the strength in this desirable performance. This encouragement and motivation has a big role in the development of total quality management program in the organization.

\subsection{The Goals of Total Quality Management.}

a. Increase the competitiveness of the organization.

b. Increase the efficiency of the organization in customer satisfaction, superiority and excellence over competitors.

c. Increase the productivity of all elements of the organization.

d. Movement and increase the flexibility of the organization in its dealings with the higher capacity variables on investment opportunities, and avoid risks and obstacles.

e. Comprehensive ensures continuous improvement for all sectors and levels and activities of the organization. 


\section{REPORT METHOD}

This report is based on descriptive and analytical approach which is based on the description and analysis of the phenomenon under study that related between Total Quality Management system and the policies and practices of human resource management in Wahda Bank in order to reach results that contribute in achieving the objectives of the report.

\subsection{Data Source.}

The type of data used in this study is preliminary data, which obtained directly from the source of this information comes from documents that have been collected, such as articles, official websites, statistics, global reporting and organizational structures of Wahda Bank. Ppolicy documents and mission statements, annual reports, minutes or meetings, codes of conduct, and every valuable source of data.

\subsection{Data Collection.}

In order to establish how to plan and tackle the report problems, it was necessary to adopt particular technique. In this way, the necessary data required to provide the answers to the report objective that was set.

\subsection{Methods of Data Analysis.}

In this report logic analysis had been used to create a bridge between the data, qualitative procedures interspersed was used to analyze the data collected for this report. Content discussion approach was used to analyze the quantitative data generated. the findings and the recommendations, which include analysis of the number of workers in Wahda Bank structure as it is known in Total Quality Management.

\subsection{History of Wahda Bank.}

\section{Result And Discussion}

Wahda Bank was established on 22.12.1970 as a result of the integration of five commercial banks operating at the time and in accordance with the provisions of Law No. 153 of 1970 on the nationalization of the foreign shares of commercial banks and reorganized.

Wahda Bank's paid-up capital is 108 million LYD, one hundred and eight million Libyan dinars. Have socio-economic development fund with $54.1 \%$ of the shares, $26.90 \%$ of the private sector and $19 \%$ for the Arab Bank which is the strategic partner.

\subsection{The Fundamental Changes Required Converting the Management System in Wahda Bank to Total Quality Management.}

Changing refers to the partial or radical modifications in the bank in order to move toward a better competitive position from which the bank achieves its objectives, in response to the sum of the affecting forces which are:

1. Internal forces: These forces are the environmental factors that arising within the bank and lead towards the change, which are:

a. Lack of job satisfaction among employees and increase the hours of work absence.

b. Weakness or lack of cooperation between the departments and employees.

c. Lower profits and incurred losses to the bank.

2. External forces: These forces arise from outside the perimeter of the bank and cannot be controlled unless the bank makes compatible changes to match these forces, and serves them as the main motivations toward the change as a result of:

a. Technological and informatics developments.

b. Issuing new banking laws and legislations.

c. Economical transformations.

d. Increasing the competition between the bank and the financial organizations.

e. The rising phenomenon of globalization by the effects of the banking business.

\subsection{Human resources and its development.}

1. The total employees in the current half-year 3110 employees compared to 3053 employees from the previous year, with an increase of 57 employees by $2 \%$.

2. The number of employees that recruited contracts for the first-half of this year 150 employees compared to 161 employees in the previous year by $6.83 \%$ deficiency as well as the number of ending their services this year, 56 employees compared to 71 employees in the previous year.

3. The number of non-clerical employees during the first-half of this year 539 employees compared to 557 employees in the previous year decrease of 18 employees and by $3.2 \%$ 


\subsection{Vision and Mission of Wahda Bank}

1 - Vision:

Wahda bank vision is to focus on continuous improvement in terms of creating appropriate environment and encouragement to the implementation of Total Quality Management concept and implement policies and procedures that lead to meet the customers' needs and effective contact with the employees and the various collaborations with the bank.

2- Mission

Wahda Bank consistently exceed customer needs and expectation by providing value of adding solutions through professional and highly motivated employees delivering excellent financial performance with the following points:

1. Ensure the provision of security and safety at work.

2. Ensure the satisfaction to the customers by focusing on the applying the procedures and the policies of total quality management in according to the international standards in providing services to the customers.

\subsection{Courses and Trainings}

During the first half of this year Wahda Bank made ten training courses attended by 100 trainees from different departments in the bank. The overall training programs for employees dealt with various topics such as:

1. Conversational skills in English.

2. Market risk management.

3. Documentary credits workshop.

4. Treasury operations and financial

\subsection{Banking Services in Wahda Bank}

1. Make payment services instruments drawn from the customers or them and collected.

2. Services for Documentary Credits, and documents under collection and letters of guarantee.

3. Issuing and managing payment instruments including cash withdrawals, remittances and credit and payment cards, instruments and other tourist attractions.

4. Dealing with money market instruments, and capital market instruments, buying and selling, whether for its own account or for account customers.

\subsection{The Report Objectives.}

The report seeks to offer how the implementation of total quality management will improves Wahda Bank financially and socially. This report shows three important objectives to implement total quality management and improves wahda bank. Specifically the following objectives will be diligently pursued:

4.7.1 Characterize and Analyze the Policies and Practices of Total Quality Management in Wahda Bank and Determine Their Suitability for the Application of Total Quality Management Entrance.

1. Lack of interest by the senior management of Wahda Bank to importance of personnel management as a specialized function works to meet the needs of the organization of labor, auspices and the development of these workers

2. The selection and recruitment procedures that used in Wahda Bank do not fit with Total Quality Management.

3. Deficiencies in the use of modern methods that required attracting labor.

4. The methods of performance evaluation that used in the bank are traditional techniques evaluation.

4.7.2 Determine the Intellectual and Philosophical Framework for the Entrance of Total Quality Management as a Recent Trend in the Field of Human Resource Management and Administrative Method Aims to Continuous Improvement of the Quality of the Performance Within Wahda Bank.

1. Training

The contents of training should enhance the bank employees to achieve the successful implementation of the Total Quality Management, by setting up foreign global banking training courses centers and experts of foreigners in the training of human resources.

2.Performance assessment:

Develop the evaluation policies performance in the bank to fit the application of total quality management, and it can be done through:

a. Stop using the personal appreciation heads in evaluating employee's performance and use the modern methods of assessment.

b. Rely on the collective performance evaluation of employees during the work teams. 
4.7.3 Determine the Elements of the Successful Implementation of Programs and Methods to Improve the Total Quality Management Policies and Practices of Human Resource Management and the Application of This System on the Quality of Wahda Bank Services.

1. Quality of personnel: The degrees of Wahda Bank employees will go a long way to determining the extent of Total Quality Management application. If the quality is high, there is the probability that they will quickly understand the training in Total Quality Management.

2. Computerization: Computerization will speed up the processing of data and transactions such that customers spent less time on questions as opposed to the ledger cards that is used till now. Computerization generates fast service time.

3. Employees' Attitude: The attitude to work by employees also goes a long way to influencing the Total Quality Management implementation. If the attitudes of the workers are negative, Total Quality Management will not be successfully implemented.

4. Awareness of the bank objectives: If the employees are aware of organizations objectives they will work towards achieving the objectives. But a situation is if the employees did not know the objectives of the bank, the employees will only believe that whatever they are doing is the right thing.

\subsection{The Results.}

Results of the study showed the following:

1. Lack of interest by the senior management of Wahda Bank to importance of personnel management as a specialized function works to meet the needs of the organization of labor auspices and the development of these workers while they must adopt and publish the concept of Total Quality Management in the bank.

2. The selection and recruitment procedures that used in Wahda Bank does not fit with Total Quality Management, where are the selection and recruitment procedures through the Office of Manpower which loses the bank its ability in the selection and recruitment employees with scientific and technical skills that fit with the nature of the bank work, which means it does not use selective recruitment depends upon Total Quality Management in the selection and recruitment procedures. This selection and recruitment procedures must change to the use of modern methods of assessment such as 360 degrees assessment angle to evaluate the performance of the employees.

3. Deficiencies in the use of modern methods in attracting labor required, such as the browsing mail through the international information network (Internet) to get the skills and experience required.

4. The methods of performance evaluation that used in the bank is a traditional techniques evaluation depends on evaluating the performance of employees on the personal estimation of managers only (Direct manager + Chairman + General Manager) and thus does not reflect the true performance of the employee which it does not used modern methods of assessment. Where the bank must use modern methods of evaluation such as the overall assessment, which will be more realistic in assessing where the employee depends more on the performance evaluation (Presidents + colleagues + customers + evaluation of the employee for himself)

\section{FIGURES AND TABLES}

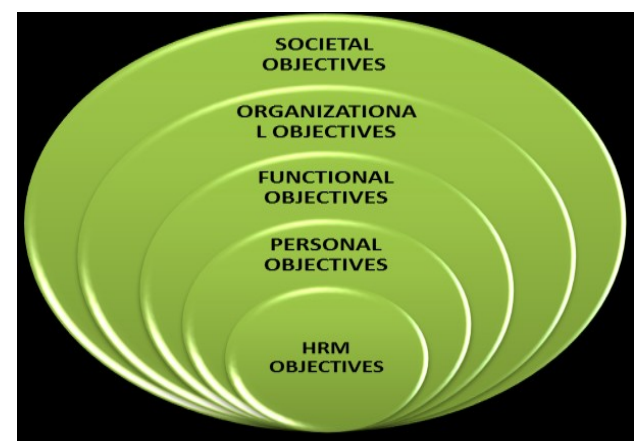

Figure1. The Objectives of Human Resource Management 




Figure2 Shareholders of Wahda Bank (Annual Report of Wahda Bank 2012)

Table1. The Total Employees in 2012 the First-half of 2013

\begin{tabular}{|l|c|c|c|c|}
\hline Categories of & \multicolumn{2}{|c|}{$\mathbf{2 0 1 2}$} & & \multicolumn{2}{c|}{ First-half } & 2013 \\
\hline Employees & Number & Percentage & Number & Percentage \\
\hline Local employees & 2493 & $81.65 \%$ & 2560 & $82.32 \%$ \\
\hline Non-local employees & 3 & $0.10 \%$ & 11 & $0.35 \%$ \\
\hline $\begin{array}{l}\text { Non-clerical } \\
\text { employees }\end{array}$ & 557 & $18.25 \%$ & 539 & $17.33 \%$ \\
\hline Total & 3053 & $100 \%$ & 3110 & $100 \%$ \\
\hline
\end{tabular}

Table2. The Total of Recruited Contracts Employees in Wahda Bank

\begin{tabular}{|c|c|c|c|c|c|c|c|c|c|}
\hline Statement & $\begin{array}{c}\text { Contract } \\
\text { terminated }\end{array}$ & Death & Retire & Deficit & Expel & Transfer & Resign & Total \\
\hline 2012 & 6 & 5 & 26 & 3 & 5 & 3 & 23 & 71 \\
\hline 2013 & 3 & 7 & 19 & 1 & 6 & 1 & 19 & 56 \\
\hline
\end{tabular}

Table3. The Total of Non-clerical Employees in Wahda Bank

\begin{tabular}{|c|c|c|c|c|c|c|c|c|c|}
\hline Job & Driver & Reporter & Technician & Electrical & Chef & Sentry & Photography & Cleaner & Total \\
\hline 2012 & 103 & 153 & 15 & 8 & 6 & 175 & 5 & 92 & 557 \\
\hline 2013 & 99 & 148 & 16 & 7 & 8 & 166 & 6 & 89 & 539 \\
\hline
\end{tabular}

Table4. Wahda Bank Training Course in The first quarter of 2013

\begin{tabular}{|c|c|c|}
\hline Training courses & training hours & The number of employees \\
\hline documentary credits and letters of guarantee & 20 & 40 \\
\hline Archiving and save documents & 20 & 40 \\
\hline International norms for Documentary Credits UCP-600 & 20 & 40 \\
\hline Overall banking business & 60 & 40 \\
\hline $\begin{array}{l}\text { Procedures for granting credit facilities for institutions and } \\
\text { companies }\end{array}$ & 20 & 20 \\
\hline Audit and Inspection & 20 & 40 \\
\hline Build customer relationship management (CRM) & 40 & 50 \\
\hline
\end{tabular}

Table5. Wahda Bank Training Course in The second quarter of 2013

\begin{tabular}{|l|c|c|}
\hline Training courses & Training hours & The number of employees \\
\hline Operating risks & 20 & 20 \\
\hline Negotiation Skills & 20 & 40 \\
\hline Selling Skills & 20 & 40 \\
\hline Audit and Inspection & 20 & 40 \\
\hline Human resources for non-employees & 20 & 40 \\
\hline $\begin{array}{l}\text { Procedures for granting credit facilities for institutions and } \\
\text { companies }\end{array}$ & 20 & 20 \\
\hline Investment portfolios & & 20 \\
\hline
\end{tabular}




\section{CONCLUSION}

This report shows that Total Quality Management confers excellence on organization. The objectives of Wahda Bank are written in clear simple language and communicated to the employees of the bank. Quality standard is to the advantage of all the customers of the bank. The level of education of the bank customers as well as the bank staff determines to a great successful of Total Quality Management implementation.

The bank has quality-training program that is aimed at achieving the bank objectives. The quality of personnel, computerization, and employees' attitude to work, awareness of organizations objectives, the motivation level and the involvement of the employees in decision making all determine the quality of banking services from the report.

The bank objectives should be such that is circulated so that every employee will be able to personally assess their contribution. This report shows that the bank customers, bank employees and management must work together to achieve the quality standard expected of them for successful implementation of Total Quality Management.

\section{REFERENCES}

[1]. Abdel-Mohsen, Tawfik Mohamed. (1996) "Planning and quality control of products / entrance of Total Quality Management", Egypt, the Arab Renaissance House Publishers.

[2]. Al-Saqqaf, Abdullah Hamad. (2008). "The mass entrance of TQM", Saudi Arabia.

[3]. Aalbregtse, R.J., Heka, J.A. and McNeley, P.K.(1991). "TQM: How do you do to do it?".

[4]. Banfield, Paul. Kay, Rebecca. (2008). "Introduction to Human Resource Management". 1st edition, p63.

[5]. Berry, T. (1991). "Managing the Total Quality Transformation". N.Y: McGraw-hill, Inc.

[6]. Currie, T.A. (1997). "Total Quality Management in Georgia Post Secondary Technical Institutes" Ph. d. diss. University of Georgia.

[7]. Dessler, Gary. (2011-12). "Human Resource Management". 12th Edition. Florida international University: Pearson Book Company.

[8]. Flippo, Edwin B. (1984). "Personnel Management" Sixth Edition, McGraw- Hill, New York, p. 114. 3.

[9]. Gilbert, G. (1992). "Quality Improvement in a Defense Organization." Public Productivity and Management Review, 16(1), 65-75.

[10]. Hussein, Khaled Sami Abulkhair Mohamed. (2006). "Performance management - lessons learned": total quality management and human resources management. 